\title{
Kausiväestö moninaistaa kuvaa aluerakenteen kehityksestä Suomessa
}

\author{
OLLI LEHTONEN $^{1}$, OSSI KOTAVAARA ${ }^{2}$, TOIVO MUILU ${ }^{3}$, \\ HILKKA VIHINEN ${ }^{3} \&$ JANNE HUOVARI ${ }^{4}$ \\ Itä-Suomen yliopisto ${ }^{1}$, Oulun yliopisto ${ }^{2}$, Luonnonvarakeskus $^{3} \&$ Pellervon taloustutkimus ${ }^{4}$
}

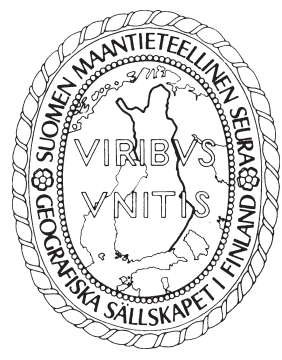

Lehtonen, Olli; Ossi Kotavaara; Toivo Muilu; Hilkka Vihinen \& Janne Huovari (2020). Kausiväestö moninaistaa kuvaa aluerakenteen kehityksestä Suomessa (The seasonal population diversifies the picture of development of the regional structure). Terra 132: 2, 69-84. https://doi.org/10.30677/terra.85022

$\boldsymbol{y}$ Multi-local living and spatial interaction are expected to change the picture of regional development, as they emphasize the seasonal and interrelated use of areas. The article focusses on questions: In what kind of spatial formation is the regional structure in Finland divided, and how common are these spatial formations in the regional structure? The results from the spatial cluster analysis show that the development of the regional structure is more diverse than previously known. Geographically, the dominating areas are seasonally growing areas which had remarkable increase in the seasonal use of areas. The results also showed that growth was more common in the regional structure than previously known, and the growth network extended from southern Finland to Lapland. The spatial formation of the stagnating areas was previously known to be narrower and more fragmented, as only a quarter of the surface area was classified as stagnating areas. The identifying of the diversity of the regional structure is essential for producing an exact picture of regional development for the needs of regional development and policy.

Key words: regional structure, seasonal population, spatial clustering, Finland

Olli Lehtonen, Department of Geographical and Historical Studies, University of Eastern Finland, P. O. Box 111, FI-80101 Joensuu, Finland. E-mail: <olli.lehtonen@uef.fi>

Suomen aluerakenteen kehityksen yleiskuvaa hallitsee käsitys muutamasta kasvavasta kaupunkiseudusta ja niitä ympäröivistä laajoista taantuvista alueista. Tutkimusten mukaan aluerakenteen kehitys on keskittyvää (Tervo 2019). Tulkintaa vahvistavat kuntien välisen muuttoliikkeen ja väestönkasvun keskittyminen 1990- ja 2000-luvuilla vain muutamille suurimmille kaupunkiseuduille, kun puolestaan pienet kaupunkiseudut ja maaseutu kärsivät muuttotappiosta ja luonnollisesta väestön vähenemisestä (Hanell ym. 2002; Aro 2007; Lehtonen 2015a). Keskittymisen seurauksena peräti 90 prosenttia Suomen pinta-alasta oli poismuuttoaluetta vuosina 1995-2000 (Hanell ym. 2002). Väestöennusteissa keskittyvän kehityksen ennakoidaan jatkuvan myös tulevaisuudessa (MDI 2019).

Yllä esitetty tulevaisuudenkuva aluerakenteesta perustuu pääosin väestö- ja muuttoliiketilastoihin nojautuviin tutkimuksiin, jotka ottavat vain rajoitetusti huomioon muita aluekehitykseen vaikuttavia tekijöitä. Erityisen huonosti aikaisemmat tulkinnat tavoittavat ihmisten kausittaista liikkuvuutta ja sen myötä alueiden toimintaan laajalti vaikuttavaa monipaikkaisuuden dynamiikkaa (Pitkänen \& Strandell 2018; Alasalmi ym. 2020). Tämä johtuu siitä, että aikaisemmissa tutkimuksissa aluerakenteen tarkastelua on tehty tilastoidulla väkiluvulla, joka perustuu henkilön asuinpaikkaan vuoden viimeisenä päivänä. Esimerkiksi Suomessa kausiväestön lukumäärä on kasvanut 1,6 miljoonasta 2,4 miljoonaan vuosien 1990 ja 2016 välillä (Alasalmi ym. 2020). Tämän väestöryhmän liikkuminen vuoden aikana muovaa oletettavasti merkittävästi aluerakennetta, joten sen ottaminen huomioon analyysissä on perusteltua.

Toinen ero aiempiin tutkimuksiin verrattuna on se, että tässä artikkelissa hyödynnetään geospatiaalisen tutkimuksen uusia tutkimusmenetelmiä, jotka mahdollistavat entistä paremmin alueiden välisen vuorovaikutuksen tarkastelun osana aluerakenteen kehitystä. Monissa aiemmissa tutkimuksissa alueiden välistä vuorovaikutusta ei ole huomioitu (Lehtonen 2015a), vaikka ihmistoiminta ei nouda- 
ta alueellisia ja hallinnollisia rajoja, ja esimerkiksi muuttoliikkeen ja huono-osaisuuden on Suomessa havaittu ryvästyvän maantieteellisesti (esim. Lehtonen \& Tykkyläinen 2010). Tämän ryvästymisen taustalla vaikuttavat maantieteellisen tilan ominaisuudet ja ihmisten liikkumisesta seuraava alueiden välinen maantieteellinen vuorovaikutus. Vuorovaikutuksen huomioon ottaminen oletettavasti muokkaa kuvaamme aluerakenteen kehityksestä monisävytteisemmäksi häivyttäen mustavalkoista jaottelua kasvaviin ja taantuviin alueisiin.

Tässä artikkelissa päivitetään tilannekuva Suomen aluerakenteen kehityksestä vuosina 20052016. Artikkelissa kysytään, millaiset aluemuodostumat kuvaavat aluerakenteen kehitystä Suomessa, ja mikä on näiden aluemuodostumien esiintyvyys aluerakenteessa. Aluemuodostumiksi kutsutaan artikkelissa spatiaalisessa ryhmittelyanalyysissä muodostuvia ryhmiä, jotka kuvaavat aluerakennetta ottaen huomioon pysyvän asutuksen, työssäkäynnin sekä ihmisten kausittaisen liikkumisen. Menetelmänä käytettävä spatiaalinen ryhmittelyanalyysi ottaa huomioon alueiden välisen vuorovaikutuksen ja kuvaa tähän pohjautuen aluerakennetta uudella tavalla. Monipaikkaisuus ymmärretään tässä artikkelissa vapaa-ajan asumisena, sillä se on monipaikkaisen asumisen muodoista volyymiltaan merkittävin ja kesämökkien maantieteellisen jakautumisen avulla parhaiten arvioitavissa (Adamiak ym. 2017; Pitkänen \& Strandell 2018).

\section{Aluerakennetta käsittelevä tutkimus}

\section{Aluerakenteen kehitykseen vaikuttavat tekijät}

Aluerakenteella tarkoitetaan asumisen, palveluiden, tuotannon, työpaikkojen, vapaa-ajanalueiden ja liikennejärjestelmien muodostamaa kokonaisuutta sekä näiden sisäisiä ja keskinäisiä toiminnallisia vuorovaikutussuhteita (Rissanen ym. 2013; Ristimäki ym. 2017). Kyseessä on siis laaja yläkäsite, jonka avulla tarkastellaan suurten toiminnallisten aluekokonaisuuksien kuten maakuntien asunto-, työmarkkina- ja talouskehitystä tai alueiden välisiä suhteita.

Suomen aluerakenteen erityispiirre 2000-luvulla on ollut alueiden ja kuntien eriytyminen keskittävän aluekehityksen takia (Tervo 2010; Lehtonen \& Tykkyläinen 2009; Lehtonen \& Tykkyläinen 2012). Tämä kehityskulku voimistui 1990-luvun laman jälkeen (Tervo 2000) ja jatkuu edelleen siten, että muutamat kaupunkiseudut kasvavat ja vastaavasti laajat alueet menettävät väestöään. Alueellinen epätasapaino aluerakenteessa on li- sääntynyt (Tervo 2019), sillä kasvavia alueita on aiempaa vähemmän (Lehtonen 2015a).

Väestöä ja toimintoja keskittävä eli polarisoiva aluekehitys on näkynyt Suomen työpaikkakehityksessä, kun laman jälkeisinä vuosina työpaikat ovat sijoittuneet enenevässä määrin suurimpiin kuntiin. Samalla on siirrytty tutkimus- ja kehitysintensiivisempään osaamiskeskusperustaiseen talouteen (Krugman 1991; Partridge ym. 2007; Lehtonen 2015b). Työpaikkojen lukumäärän kehityksen perusteella taloudellinen aktiivisuus kasvoi joka puolella Suomea vuosina 2005-2010, mutta erityisesti kaupunkialueilla, joiden osuus 101286 työpaikan kasvusta oli 79,8 prosenttia (Helminen ym. 2014). Urbanisaation eteneminen vaikuttaa erityisesti maaseudun paikalliskeskuksiin ja kaupunkien läheiseen maaseutuun, mutta ei niinkään ydinmaaseutuun ja harvaan asuttuun maaseutuun, jotka ovat jo menettäneet suuren osan väestöstään (Tervo ym. 2018).

Aluerakenteen keskittymistä ja kaupunkialueiden menestymistä on selitetty uuden talousmaantieteen teorioilla (New Economic Geography), joissa taloutta kuvataan yritystoiminnan kannalta keskeisimmillä, maantieteellisesti vaihtelevilla kustannustekijöillä (Fujita ym. 1999; Combes ym. 2008). Kaupunkiseutujen kasvua pidetään talouden teolliseen ja jälkiteolliseen vaiheeseen kuuluvana kehityksenä, joka on seurausta innovaatioihin perustuvista kasvuprosesseista, urbanisaatio- ja lokalisaatioeduista, työvoiman liikkuvuudesta ja kehittyvästä logistiikasta (Fujita ym. 1999; Tervo 2000; Rosenthal \& Strange 2004; Lehtonen \& Tykkyläinen 2012a; Felipe ym. 2012).

Kaupunkialueiden menestymisen taustalla vaikuttaa muitakin tekijöitä, kuten suotuisa ja kasvualtis keskittymisetuja hyödyntävä elinkeinorakenne (Shearmur \& Polese 2007), väestön ominaisuudet sekä tietoyhteiskunnan keskeisten tuotantotekijöiden alueelliset ominaisuudet (Glaeser 1998; Tervo 2000; Lehtonen \& Tykkyläinen 2012a). Kaupunkien vaikutusalueiden ulkopuolella esimerkiksi epäsuotuisat luonnonolosuhteet ja sijainti rajaseudulla lisäävät epäedullisesta sijainnista aiheutuvia kustannuksia (Tervo 2009; Lehtonen \& Tykkyläinen 2012a). Keskittyvän kehityksen myötä alueen etäisyys kasvaviin keskuskuntiin määrittää kuntien kehityspotentiaalia, ja näin alueellinen väestö ja aluerakenne kehittyvät maantieteellisesti epätasapainoisesti (Lehtonen \& Tykkyläinen 2010). Elinkeinorakenteen muutoksen jatkuessa nykyiseen tapaan uuden talousmaantieteen teoriat selittävät deduktiivisesti, miksi väestö keskittyy maantieteellisesti suurimmille kaupunkiseuduille, ja miksi alueiden väliset erot syvenevät eikä kehityksen suunta muutu helposti (Krugman 1991; Lehtonen \& Tykkyläinen 2012b). 
Aluerakenteessa alueen sijainnin merkityksen korostuminen näkyy kehityksen kaksinapaistumisena eli polarisaationa. Kaukana keskuskunnista sijaitseville perifeerisille ja taantuville alueille on syntynyt sijaintihaittaa, koska ne eivät ole hyötyneet keskusten myönteisen kehityksen leviämisestä (Partridge ym. 2007). Erityisesti siinä tapauksessa, että maakuntakeskus on kasvanut nopeasti, keskuksen kehitys on heikentänyt reuna-alueiden kehityspotentiaalia (Tervo 2009). Kasvukeskusten läheiset alueet ovat puolestaan voineet hyötyä näistä leviämisvaikutuksista, ja näin aluerakenteeseen on syntynyt laajojen taantuvien aluemuodostumien sisälle kasvusaarekkeita (Lehtonen 2015a). Suomessa kaupungin ja maaseudun välistä vuorovaikutusta (rurban) kuvaavat leviämisvaikutukset ulottuvat kaupunkien läheiselle maaseudulle eli käytännössä työssäkäyntivyöhykkeelle. Kaupungistumisen myötä kaupunkien läheisillä maaseutualueilla väkiluku kasvoi noin 20000 asukkaalla vuosina 2000-2012 (Helminen ym. 2014).

Uusimmassa tilastoituun väkilukuun perustuvassa väestöennusteessa vain Helsingin, Tampereen ja Turun seudut kasvavat selvästi vuoteen 2040 mennessä (MDI 2019). Vaikka ennusteet perustuvat ainoastaan viime vuosien kehitykseen, ne voivat silti toteutua, koska aluekehitysprosesseja on kuvattu maantieteellisen ryvästymisen ohella myös polkuriippuviksi (Cumbers \& MacKinnon 2004; Martin \& Sunley 2006). Keskittyvä kehitys voi lukittua pitkäksi aikaa, mikä johtaa aluerakenteen epätasaiseen kehitykseen ja alueiden pysyvään jakoon suppeisiin kasvualueisiin ja laajoihin taantuviin alueisiin (Lehtonen 2015a). Suomessa tutkimusnäyttöä on erityisesti nettomuuttoliikkeeseen kytkeytyvän väestökasvun lukittumisesta talouden nousukausien ajaksi muutamaan kasvukeskukseen vuosina 1980-2013 (Lehtonen \& Tykkyläinen 2017).

Suomen aluerakenteessa kasvusaarekkeiden halkaisija on ollut eri kokoisten keskusten ympärillä 60-120 kilometriä (Lehtonen 2015b). Itä-Suomessa kasvu ulottui enimmillään 35 kilometrin päähän keskuksista (Lehtonen \& Tykkyläinen 2012). Samat lainalaisuudet koskevat työssäkäyntialueita, sillä suurilla kaupunkikeskuksilla on laajimmat työssäkäyntialueet (Helminen ym. 2012). Väestönkasvu on yhteydessä myös saavutettavuuteen, sillä väestön on havaittu keskittyneen alueille, joilla potentiaalinen saavutettavuus tieverkkoa pitkin on hyvä (Kotavaara ym. 2011). Samankaltaista aluerakenteen kaksinapaistumista on havaittu myös muissa maissa. Näitä havaintoja ei kuitenkaan voi suoraan verrata suomalaiseen kehitykseen, sillä asutusrakenne ja väentiheys ovat erilaiset eri maissa. Esimerkiksi Kanadassa talouskasvun työllisyysja väestövaikutukset ulottuvat jopa 175 kilometrin päähän kaupunkikeskuksista (Partridge ym. 2007: 147). Toisen kanadalaisen tutkimuksen mukaan keskusten vaikutukset ulottuvat kuitenkin vain noin tunnin ajomatkan eli noin 80-100 kilometrin etäisyydelle keskuksista (Polèse \& Shearmur 2004).

\section{Monipaikkaisuus osana aluerakennetta}

Väestörakenteen kehitystä tarkastellaan Suomessa tilastoidun väkiluvun perusteella. Se kuvaa kuitenkin puutteellisesti aluerakenteen kehitystä, sillä lisääntyneen liikkuvuuden myötä ihmisten monipaikkaisuus on yleistynyt (Adamiak ym. 2017; Pitkänen \& Strandell 2018). Monipaikkaisuus koostuu eri paikoissa tapahtuvasta liikkumisesta, palveluista, työstä, harrastuksista, kokemuksista ja asumisesta (Haukkala 2011: 6), ja sen on todettu muuttavan merkittävällä tavalla erityisesti maaseutualueiden väestöpohjaa (Müller \& Hall 2003). Asumisen monipaikkaisuus (residential multi-locality) on monimutkainen sosiaalinen ilmiö, jossa painottuvat tapauskohtaiset ja elämäntilanteeseen liittyvät tekijät. Monipaikkaiselta asumiselta puuttuu teoreettinen määritelmä ilmiön moniulotteisuuden vuoksi (Weichhart 2015). Monipaikkaisuus liittyy globalisaatioon, työmarkkinoiden joustavuuden lisääntymisen sekä kotitalouksien vaurastumiseen ja perherakenteiden murrokseen (Alasalmi ym. 2020), jota vauhdittaa digitalisaation mahdollistama paikkariippumattomuus.

Monipaikkaisuutta ei oteta huomioon aluerakenteen kehityksen seurannassa eikä sitä koskevassa päätöksenteossa tai aluesuunnittelussa. Suomalainen yhteiskunta perustuu suurelta osin oletukseen yksipaikkaisuudesta, joka ilmenee siten, että yhdyskuntarakennetta ja palveluita suunnitellaan, seurataan ja kehitetään pääsääntöisesti pysyvän tilastoidun väkiluvun perusteella. Valtionvarainministeriön julkaiseman raportin Millaista monipaikkaisuutta Suomeen - selvitys kaksoiskuntalaisuudesta (2018: 69) mukaan monipaikkaisuus tulee kuitenkin nähdä "voimavaralähtöisenä toiminnan kehittämisenä kunnan sekä kunnassa toimivien yhteisöjen ja ihmisten omista ja paikallisista lähtökohdista".

Suomessa monipaikkaisuutta on tutkittu lähinnä vapaa-ajan asumisen näkökulmasta (Alasalmi ym. 2020). Painotusta selittää se, että vapaa-ajan asuntoja on yli puoli miljoonaa. Lisäksi useissa kunnissa vapaa-ajan asumisen maa-ala on suurempi kuin vakituisen asumisen (Adamiak ym. 2017). Aluerakenteessa on siten yhä enemmän alueita, joita käytetään vain osan aikaa vuodesta. Talviasuttavien kesämökkien yleistyminen ja mökkien käyttöajan lisääntyminen ovat kuitenkin hälventäneet kesämökin ja asunnon rajaa. Tämä tarkoittaa sitä, että vapaa-ajan asunnolla vietetään 
entistä pidempiä aikoja (Mökkibarometri 2016; Tilastokeskus 2020), ja ne koetaan yhä useammin pikemminkin kakkosasuntoina kuin kesämökkeinä (Kaltenborn 1998; Pitkänen \& Vepsäläinen 2008; Adamiak ym. 2015). Myös vapaa-ajan asuntojen toiminnallisuus on lisääntynyt ja kesämökiltä käydään töissä aikaisempaa useammin, vaikka iso osa kesämökkien omistajista on eläkeläisiä. Mökkibarometrin (2016) kysely toteutettiin lokajoulukuussa 2015 ja sen mukaan 18 prosentilta eli noin 100000 kesämökiltä käytiin töissä vuonna 2015 keskimäärin 27 päivänä vuodessa. Lisäksi 10 prosentilta eli noin 60000 kesämökillä tehtiin etätöitä keskimäärin 12 työpäivää vuodessa (Mökkibarometri 2016). Tästä huolimatta vapaa-ajan asukkaat tilastoituvat asukkaiksi vain vakituisille asuinpaikkakunnilleen.

Vaikka monipaikkaista kausiväestöä ei tilastoida, ovat monet sen vaikutukset alueella samankaltaisia kuin pysyvän väestön. Mökkibarometrin (2016) mukaan mökkeilyyn käytettiin Suomessa vuonna 2015 noin 6,2 miljardia euroa ja mökkeilyn työllisyysvaikutukseksi on arvioitu noin 60000 työpaikkaa. Kausiväestön paikallistalouteen kohdentamat ostot lisäävät paikallisten yritysten tuottamien palvelujen kysyntää (Saaristoasiain neuvottelukunta 2006). Kausiväestön ottaminen huomioon on tärkeää myös esimerkiksi infrastruktuurin, kuten liikenteen, tietoliikenneverkkojen, veden ja sähkön jakelun sekä jätehuollon, suunnittelussa, mitoituksessa ja hallinnassa (Adamiak ym. 2017). Tietoisuus kausiväestöstä on hyödyllistä kuvattaessa aluerakenteen kehitystä, mutta sitä voidaan hyödyntää myös aluesuunnittelussa ja -kehittämisessä.

\section{Tutkimuksen toteutus}

Aluerakenteen kehitystä on kuvattu Suomessa useilla käsitteillä ja indikaattoreilla. Keskeinen käsite 1970-luvulla oli alueellinen kehittyneisyys (esim. Alueellinen kehittyneisyys 1979). Sen sijaan 1980-luvulla keskityttiin alueellisiin hyvinvointieroihin (esim. Aronen \& Siirilä 1986). Käsite vaihtui 1990-luvulla, jolloin tutkimuksissa puhuttiin alueellisesta erilaistumisesta (esim. Vaattovaara 1998; Kainulainen ym. 2001). Alueellisen kilpailukyvyn käsite omaksuttiin käyttöön 2000-luvulla (Lehtonen \& Tykkyläinen 2012a) ja alueiden elinvoima 2010-luvulla (Jauhiainen \& Huovari 2013; Aro 2015). Toiminnallisiin kaupunkiseutuihin perustuva kaupunkiverkko nousi aluerakenteen jäsentämisen perustaksi 1990-luvulla (Vartiainen 1995). Tarkastelussa pyrittiin määrittelemään muuttujaperusteisesti kaupunkiseutujen joukko ja kaupunkien seudulliset vaikutuspiirit.
Suomen aluerakenteen kehitystä on kuvattu 1990-luvulta lähtien myös erilaisilla aluetypologioilla. Ensimmäinen maaseututypologia laadittiin vuonna 1993 (Keränen ym. 1993). Vuosina 20052006 kehitetty kuntapohjainen maaseututyypittely tuotettiin alun perin maaseutupolitiikan ja aluekehityspolitiikan tarpeisiin (Malinen ym. 2006). Kuntaa tarkemmalle aluetasolle päästiin tilastoruutuperustaisilla väestötiedoilla (Rusanen ym. 2003). Kun kuntapohjainen tarkastelu todettiin riittämättömäksi 2010-luvulla, aluekehitystä laajemmin tarkastelevassa kaupunki-maaseutu -luokituksessa hyödynnettiin väestöruuduttaisia paikkatietoja (Helminen ym. 2014). Kehittyvien paikkatietomenetelmien myötä myös saavutettavuusanalytiikka vakiintui osaksi alue- ja kaupunkirakenteen tarkastelua 2010-luvulla (Kotavaara ym. 2012; Toivonen ym. 2010). Sittemmin alueiden omiin vahvuuksiin perustuvan kilpailukyvyn parantamista aluepolitiikassa on toteutettu muun muassa kasvuvyöhykkeiden avulla (Työ- ja elinkeinoministeriö 2020). Toistaiseksi alueiden spatiaaliseen kytkeytymiseen ja monipaikkaisuuteen ei ole kiinnitetty huomiota suomalaisissa aluerakenteen tutkimuksissa.

\section{Tutkimusaineistot}

Tässä artikkelissa aluerakenteen kehityksen muutosta kuvataan väestön ja työpaikkojen lukumäärän muutoksilla sekä työssäkäyntiä ja työmatkojen pituuksia kuvaavilla muuttujilla. Muuttujajoukkoa perustellaan sillä, että nämä muuttujat korreloivat voimakkaasti muiden yksittäisten aluekehityksen menestystä mittaavien tekijöiden kanssa (Niemi 2002). Aluerakenteen kehitystä kuvaavat muuttujat ovat peräisin YKR- (Yhteiskuntarakenteen seurantajärjestelmä) ja Paavo -tietokannoista (taulukko 1). YKR-tietokanta sisältää muuttujia väestöruudun väestörakenteesta, asumisesta, työpaikoista, työvoimasta ja rakennuksista (Suomen ympäristökeskus 2013). Paavo -tietokanta sisältää samoja tietoja kuin YKR -tietokanta, mutta alueyksikkönä ovat postinumeroalueet (Tilastokeskus 2016).

Käytämme tutkimuksessamme postinumeroaluejakoa siitä syystä, että se on riittävän pieni yksikkö alueellisten erojen kuvaamiseen, mutta riittävän suuri aluekehitystä kuvaavien muuttujien satunnaisvaihtelujen hallintaan. Paavo -tietokantaa täydennettiin sen aikaisemmalla versiolla eli SuomiCD -tietokannalla, josta oli mahdollista poimia väestön ja työpaikkojen lukumääriä kuvaavat muuttujat vuodelta 2005 (Tilastokeskus 2006). Valitulle tarkastelujaksolle 20052016 ajoittuivat vuoden 2008 finanssikriisi ja vuoden 2011 eurokriisin jälkeinen taantuma sekä niitä seuranneet nousukaudet. Tällä aikavälillä työpaikkojen lukumäärä postinumeroalueilla kasvoi 15 121:1lä. 
Taulukko 1. Aluerakenteen tarkastelussa käytetyt muuttujat.

Table 1. Variables used in the regional structure analysis.

\begin{tabular}{|c|c|c|c|}
\hline $\begin{array}{l}\text { Muuttuja } \\
\text { (Variable) }\end{array}$ & $\begin{array}{l}\text { Kuvaus } \\
\text { (Description) }\end{array}$ & $\begin{array}{l}\text { Aineistolähde } \\
\text { (Data source) }\end{array}$ & $\begin{array}{l}\text { Vuosi } \\
\text { (Year) }\end{array}$ \\
\hline $\begin{array}{l}\text { Väkiluvun muutos } \\
\text { (Change of registered population) }\end{array}$ & $\begin{array}{l}\text { Pysyvän tilastoidun väkiluvun suhteellinen muutos vuosina 2005-2016 } \\
\text { (\%) } \\
\text { (Change in registered population } 2005-2016(\%) \text { ) }\end{array}$ & $\begin{array}{l}\text { Paavo ja } \\
\text { SuomiCD }\end{array}$ & 2005-2016 \\
\hline $\begin{array}{l}\text { Kausiväestön lukumäärän muutos } \\
\text { (Change of seasonal population) }\end{array}$ & $\begin{array}{l}\text { Kausiväestön lukumäärän suhteellinen muutos vuosina 2005-2016 (\%) } \\
\text { (Change in seasonal population 2005-2016 (\%)) }\end{array}$ & YKR & 2005-2016 \\
\hline $\begin{array}{l}\text { Kausiväestön erotus tilastoituun } \\
\text { väkilukuun (\%) } \\
\text { (Difference between seasonal and } \\
\text { registered population) }\end{array}$ & $\begin{array}{l}\text { Kausiväestön ja pysyvän tilastoidun väkiluvun erotus suhteessa } \\
\text { pysyvään väkilukuun vuonna } 2016 \text { (\%) } \\
\text { (Difference between seasonal and registered population in } 2016(\%) \text { ) }\end{array}$ & YKR ja Paavo & 2016 \\
\hline $\begin{array}{l}\text { Työpaikkojen lukumäärän muutos } \\
\text { (Change in the number of jobs) }\end{array}$ & $\begin{array}{l}\text { Työpaikkojen lukumäärän suhteellinen muutos (\%) } \\
\text { (Relative change in the number of jobs in 2005-2016 (\%)) }\end{array}$ & $\begin{array}{l}\text { Paavo ja } \\
\text { SuomiCD }\end{array}$ & 2005-2016 \\
\hline $\begin{array}{l}\text { Työpaikkaomavaraisuus } \\
\text { (Workplace self-sufficiency) }\end{array}$ & $\begin{array}{l}\text { Alueella työssäkäyvien ja alueella asuvan työllisen työvoiman määrän } \\
\text { välinen suhde (\%). Jos työpaikkaomavaraisuus on yli } 100 \% \text {, on alueen } \\
\text { työpaikkojen lukumäärä suurempi kuin alueella asuvan työllisen } \\
\text { työvoiman lukumäärä. Jos taas työpaikkaomavaraisuus on alle } 100 \% \text {, } \\
\text { on tilanne päinvastainen. } \\
\text { (Self-sufficiency in workplaces indicates the ratio between the number } \\
\text { of people working in the area and the employed labour force living in } \\
\text { the area. If the ratio exceeds } 100 \% \text {, the number of workplaces in the } \\
\text { area is greater than the number of employed people living in the area. } \\
\text { If the figure is below } 100 \% \text {, the opposite is true.) }\end{array}$ & YKR & 2016 \\
\hline $\begin{array}{l}\text { Työmatkan pituus } \\
\text { (Commuting distance) }\end{array}$ & $\begin{array}{l}\text { Postinumeroalueen työmatkojen keskipituus }(\mathrm{km}) \\
(\text { Average commuting distance }(\mathrm{km}))\end{array}$ & YKR & 2016 \\
\hline $\begin{array}{l}\text { Työmatka yli 100km } \\
\text { (Commuting distance over } 100 \mathrm{~km} \text { ) }\end{array}$ & $\begin{array}{l}\text { Yli } 100 \mathrm{~km} \text { työmatkojen osuus postinumeroalueen työmatkoista (\%) } \\
\text { (Commuting trips account for more than } 100 \mathrm{~km} \text { of commuting trips in } \\
\text { the postal code area (\%)) }\end{array}$ & YKR & 2016 \\
\hline $\begin{array}{l}\text { Työttömyysaste } \\
\text { (Unemployment rate) }\end{array}$ & $\begin{array}{l}\text { Työttömyysaste laskettuna työttömien lukumäärän ja työvoiman } \\
\text { välisenä suhteena (\%) } \\
\text { (Unemployment rate calculated as the ratio of the number of } \\
\text { unemployed of the labor force (\%)) }\end{array}$ & Paavo & 2016 \\
\hline
\end{tabular}




\section{Kausiväestön laskenta ja sen kehitys 2005-2016}

Kausiväestön sisällyttämiselle osaksi aluekehityksen tarkastelua on useita perusteita, joita käsiteltiin edellä. Vaikka kausiväestöä ei tilastoida virallisissa väestötilastoissa, sen määrää voidaan arvioida YKR -aineistossa ilmoitettujen kesämökkien lukumäärän ja aiempien vapaa-ajan asumista koskevien tutkimusten perusteella (Adamiak ym. 2017). Tässä tutkimuksessa kausiväestön määrää postinumeroalueella arvioidaan olettamalla, että jokainen, jolla on pääsy kesämökille, viettää siellä osan ajastaan. Arvio mökillä vietetyistä vuorokausista perustuu Mökkibarometrin (2016) havaintoihin, joiden mukaan kesämökillä asuttiin 79 päivää. Kausiväestön lukumäärä ei siten ole tarkka luku väestömäärästä tiettynä ajan hetkenä, vaan perusteltu arvio postinumeroalueiden suurimmasta mahdollisesta väkimäärästä kausittain. Kausiväestön lukumäärä lasketaan lisäämällä pysyvän väestön lukumäärään kesämökkien käyttäjät ja vähentämällä tästä luvusta pysyvästi postinumeroalueella asuvat, joilla on mahdollisuus käyttää heinäkuussa kesämökkiä (Adamiak ym. 2017).

Kausiväestön muutos vuosina 2005-2016 poikkesi huomattavasti tilastoidun väkiluvun kehityksestä (kuva 1). Julkisen keskustelun välittämä kuva taantuvasta maaseudusta toisin sanoen muuttuu, kun alueiden osa-aikainen käyttö otetaan huomioon. Tällöin iso osa myös harvaan asutusta maaseudusta onkin kasvattanut kausiväestöään ja kartan yleisväri muuttuu tummanharmaaksi. Vuosina 2005-2016 maaseudun kausiväestön lukumäärä kasvoi 62015 asukkaalla. Kehitys poikkeaa tilastoituun väkilukuun perustuvista havainnoista, joiden mukaan kasvu keskittyi pääosin suurimpiin keskuksiin ja niiden lähiympäristöön eli korkeintaan noin 40 kilometrin päähän keskuskaupungeista. Kausiväestön määrä kasvoi maaseudulla keskimäärin 2,3 prosenttia vuosina 2005-2016. Kasvukeskittymät sijaitsevat Järvi-Suomen alueella, rannikolla ja Lapissa (kuva 1). Näillä alueilla kausiväestö moninkertaisti alueille tilastoidun väkiluvun.

Tarkastelu osoittaa, että kaupungistuva väestö viettää yhä enemmän aikaa myös kaupunkien ulkopuolella. Siten aluerakenne yhtäältä keskittyy, mutta toisaalta hajautuu kausittain. Väestömäärän kuvaaminen vain pysyvästi siellä asuvien lukumäärällä johtaa siihen, että maaseudun väestökehitystä, palvelutarpeita, infrastruktuurin kysyntää ja alueen houkuttelevuutta asuinympäristönä kuvataan tarpeettoman synkästi. Perinteisissä väestötilastoissa yliarvioidaan kaupunkien ja aliarvioidaan harvaan asuttujen alueiden kausittaiset väkiluvut.

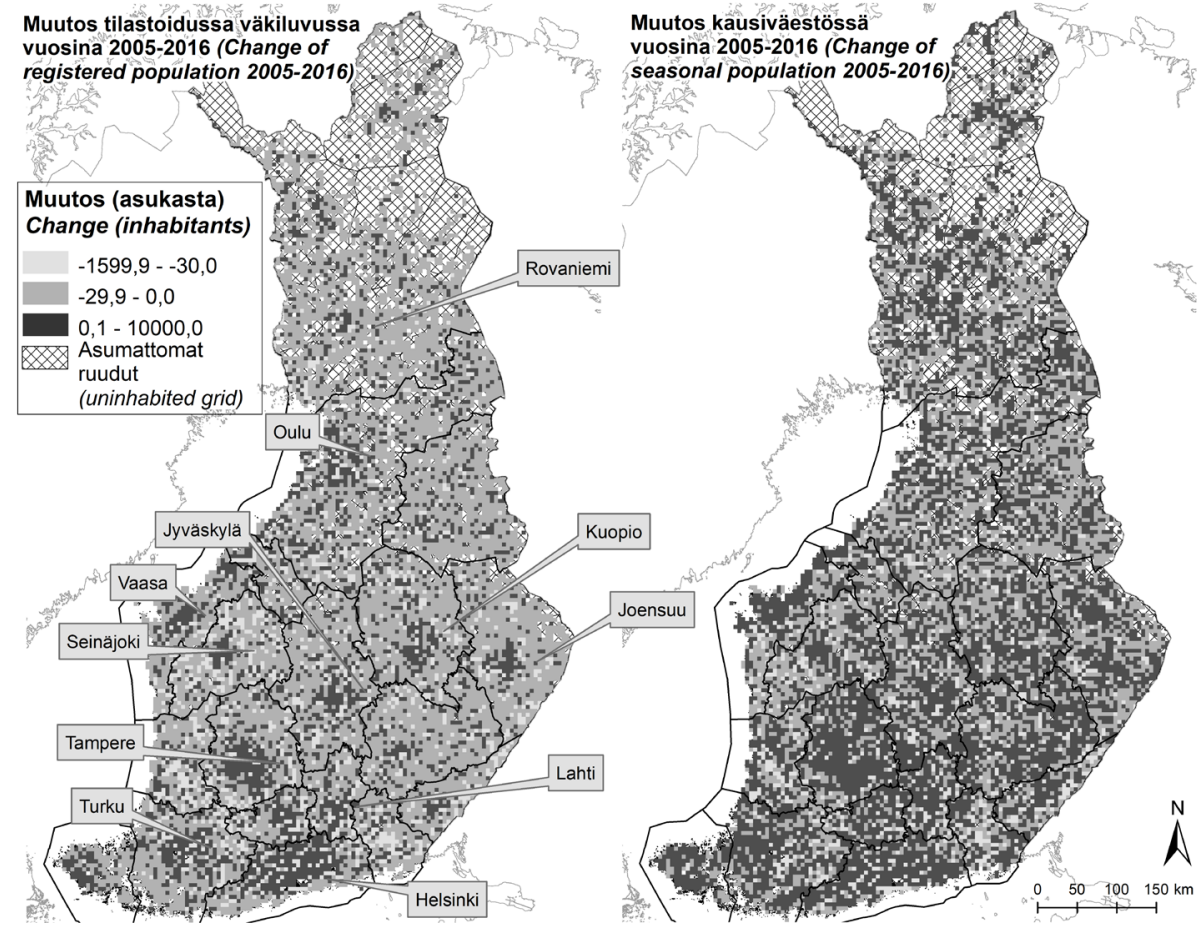

Kuva 1.

Tilastoidun ja kausiväestön muutokset $5 \mathrm{~km} * 5 \mathrm{~km}$ väestöruuduissa vuosina 2005-2016.

Figure 1. Changes in the registered and seasonal population in the $5 \mathrm{~km} * 5 \mathrm{~km}$ population squares in 2005-2016. 


\section{Spatiaalinen ryhmittelyanalyysi}

Kirjallisuudessa on esitelty useita erilaisia spatiaaliseen ryhmittelyanalyysiin perustuvia alueellistamismenetelmiä (Desjeux ym. 2015; Yurui ym. 2015). Suomessa spatiaalista ryhmittelyanalyysiä ei ole aiemmin käytetty, sillä aluerakenteen tutkimusta on tehty monimuuttujamenetelmillä (Vaattovaara 1998; Makkonen \& Inkinen 2015), naapurustovaikutusta huomioivalla regressiomallinnuksella (Helminen ym. 2012), spatiaalisilla naapurustoanalyyseillä (Helminen ym. 2014) tai yksittäisistä standardoiduista muuttujista yhteenlasketuilla summamuuttujilla (Aro 2015). Myös tilastollista mallintamista ja simulointia on käytetty alueellisen kilpailukyvyn jäsentämisessä (Lehtonen \& Tykkyläinen 2012a).

Tässä artikkelissa aluerakenteen muutosta tutkitaan soveltamalla spatiaalista ryhmittelyanalyysiä eli SKATER-algoritmia (Spatial Kluster Analysis by TreeEdgeRemoval) aluerakenteen kehitystä kuvaaviin muuttujiin. Sovellettavalla menetelmällä suuri joukko alueyksiköitä ryhmitellään osajoukkoihin, jotka ovat sisäisesti homogeenisia ja muodostavat maantieteellisesti jatkuvia alueita. Tätä menetelmää nimitetään yleisemmin alueellistamiseksi, jonka tuloksena syntyy uusia aluemuodostumia, joiden maantieteellinen kattavuus on alkuperäisiä alueyksiköitä laajempi (Assunção ym. 2006).

Menetelmän valinta pohjautui kirjallisuuskatsaukseen sekä eri menetelmillä tehtyihin kokeiluihin ja niiden tulkinnallisuuteen. SKATER-algoritmin käyttöä voidaan perustella sillä, että sen käyttö on hyödyllistä isojen aineistojen kanssa, koska menetelmällä voidaan poistaa aineistosta pienipiirteistä vaihtelua ja paljastaa aineiston keskeiset alueelliset piirteet hallinnollisista rajoista riippumatta. Siten menetelmällä voidaan kuvata aluerakennetta paremmin kuin alkuperäisellä aineistolla (Openshaw \& Alvanides 1999). Jos spatiaalista rakennetta ei sisällytetä ryhmittelyanalyysiin, eivät lopputuloksena syntyvät ryhmät välttämättä kuvaa oikein aineiston luontaista maantieteellistä aluerakennetta (Openshaw \& Wymer 1995).

SKATER-algoritmi pohjautuu naapuruussuhteiden määritykseen, jossa jokainen alue kytkeytyy naapuruussuhteiden perusteella alueiden muodostamiin solmurakenteisiin. Alueiden kytkeytymisessä lähellä olevien solmujen kustannukset eli vaikutukset muodostettaviin aliryhmiin ovat suoraan verrannollisia solmujen erilaisuuteen eli alueiden ominaisuuseroihin ja niiden väliseen etäisyyteen (Assunção ym. 2006). Solmurakenteen monimutkaisuuden rajoittamiseksi poikkeavat solmut poistetaan, kunnes saavutetaan "Minimum Spanning Tree" (MST), joka mahdollistaa sen, että alueyksiköt kytkeytyvät toisiinsa niin, että näiden välinen painotettu etäi- syys minimoituu (Pettie \& Ramachandran 2002). Lopulta algoritmissä muodostuvat erilliset solmurakenteet eli alueryhmät, jotka ovat sisäisesti mahdollisimman homogeenisiä, mutta ulkoisesti ryhmien väliset erot ovat mahdollisuuden suuria. SKATERalgoritmi on kuvattu täsmällisesti julkaisussa Assunção ym. (2006) ja se löytyy R-tilasto-ohjelman spdep-paketista. Ennen spatiaalisen ryhmittelyanalyysin suorittamista muuttujat standardisoitiin mitta-asteikkoerojen vaikutuksen poistamiseksi.

Spatiaalisessa ryhmittelyanalyysissä naapuruussuhteet määritettiin etäisyysmatriisilla, jonka säteeksi määrittyi 80 kilometriä. Valintakriteereinä käytettiin spatiaalista autokorrelaatiota (kuva 2), mutta myös 80 kilometrin työn vastaanottamisvelvoitetta, joka on työttömyysturvalaissa määritetty yksittäinen hallinnollinen määritelmä alueiden väliselle vuorovaikutukselle. Valittua sädettä voidaan perustella myös havainnoilla päivittäisestä työssäkäynnistä, jotka todentavat keskuksia ympäröivän työssäkäynnin käytännössä loppuvan 80 kilometrin etäisyydellä keskuksista (Helminen ym. 2012). Kuvasta 2 nähdään, että kynnysarvo spatiaaliselle autokorrelaatiolle on 80 kilometriä, jonka jälkeen spatiaalinen autokorrelaatio heikkenee kuvastaen alueiden välisen vuorovaikutuksen heikentymistä. Spatiaalisen etäisyysmatriisin valintaan vaikuttivat myös spatiaalisen ryhmittelyn onnistuminen sekä ryhmien väliset erot alkuperäisissä ryhmittelyssä käytetyissä muuttujissa. Lopulta iteraatioprosessissa pienimmäksi ryhmien lukumääräksi muodostui 14, koska ryhmittelyanalyysissä ryhmien lukumäärää kasvatettiin siihen asti, kunnes ryhmittelyssä muodostui poikkeavista havainnoista muodostuva ryhmä. Poikkeavan ryhmän tulokset on jätetty raportoimatta, joten tuloksissa keskitytään 13 aluemuodostuman tuloksiin.

Iteraatioprosessissa ryhmien lukumäärän valintaperusteena käytettiin ryhmäkokojen tasaisuutta sekä sitä, että ryhmät erosivat varianssianalyysissä toisista ryhmistä vähintään yhdessä ryhmittelyanalyysissä käytetyssä muuttujassa 5 prosentin merkitsevyystasolla. Ryhmittelyanalyysin onnistuminen tarkastettiin erikseen vielä lämpökartalla, jossa perinteisen hierarkkisen klusterianalyysin dendrogrammissa taantuvat, kasvavat ja kausittain kasvavat aluemuodostumat luokittuvat erillisiin haaroihin kuvastaen näiden päämuodostumien eroavaisuuksia (ks. menetelmä Hartigan 1975). Spatiaalisessa analyysissä on huomioitava, että tulokset ovat riippuvaisia alueiden kytkeytymisestä ja tähän liittyvistä valinnoista. Lisäksi on huomioitava, että tulokset voisivat erota, jos etäisyysmatriisin määrityksessä olisi käytetty esimerkiksi matka-aikaa, joka on riippuvainen alueiden saavutettavuudesta. Edellä esitetyt reunaehdot on huomioitava tulkittaessa tämän tutkimuksen tuloksia. 


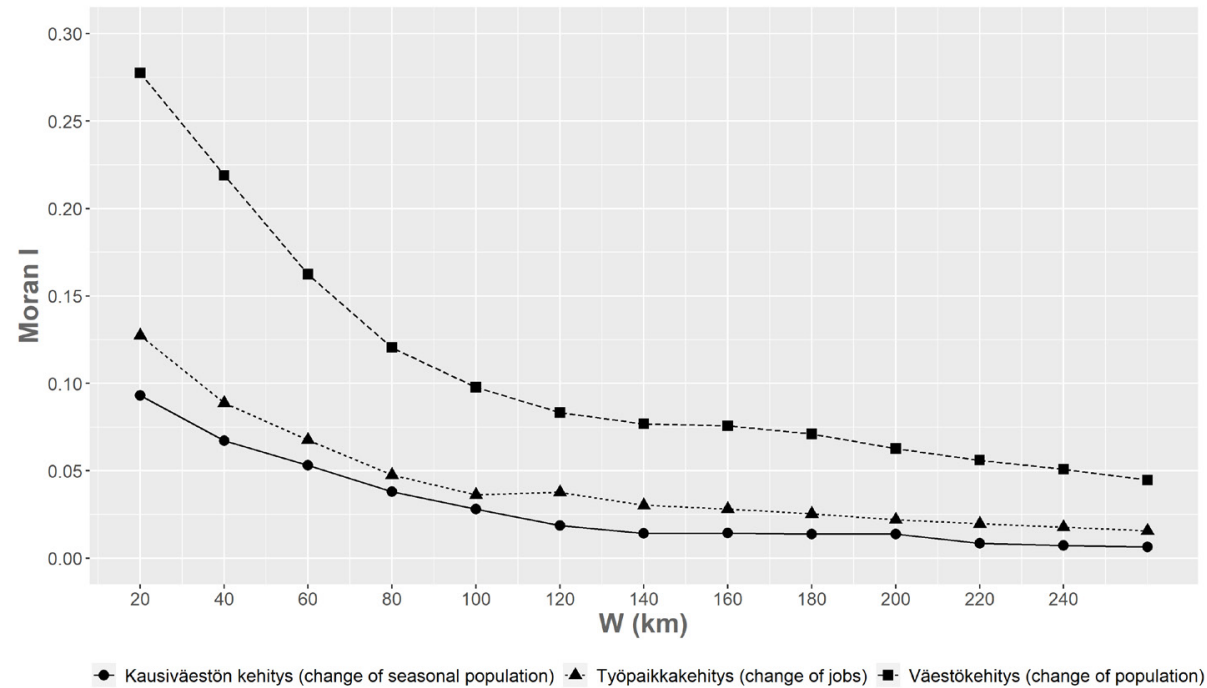

Kuva 2.

Vuosien 2005-2016 työpaikka- ja väestökehityksen spatiaalinen autokorrelaatio mitattuna Moran I indeksillä.

Figure 2.

Spatial autocorrelation of job and population development in 2005-2016 as measured by the

- Kausiväestön kehitys (change of seasonal population) - - Työpaikkakehitys (change of jobs) Moran I index.

\section{Spatiaalisen ryhmittelyanalyysin aluemuodostumat}

Aikaisempien tutkimusten tavoin spatiaalisessa ryhmittelyanalyysissä muodostui kasvavien alueiden muodostuma. Tämä aluemuodostuma jakautui ryhmittelyssä viiteen alamuodostumaan, jotka nimettiin kasvuytimeksi, kasvualueiksi ja erillisiksi kasvualueiksi tarkentamalla nimityksiä työpaikka- tai väestöliitteillä riippuen siitä, mikä oli tunnusomaista alueiden kasvulle. Kasvavien alueiden muodostumassa väkiluku kasvoi vuosina 2005-2016 yhteensä yli 311000 asukkaalla ja työpaikkojen lukumääräkin kasvoi miltei 110000 työpaikalla (taulukko 2). Kasvumuodostumat ovat aluerakenteessa työssäkäyntikeskuksia sekä niitä ympäröiviä alueita. Maantieteellisesti kasvumuodostumat painottuvat suuriin keskuksiin ja näiden ympäristöön, mutta kasvumuodostumien verkosto ulottuu myös Itä- ja Pohjois-Suomeen, mikä on tasapainoisen aluerakenteen kehityksen näkökulmasta myönteistä (kuva 3).

Ryhmittelyanalyysissä muodostui aluerakenteeseen myös aikaisemmissa tutkimuksissa havaittuja taantuvia aluemuodostumia, jotka jakautuivat tarkemmin kolmeen alamuodostumaan: väestöllisesti taantuvat alueet, kasvavan kunnan taantuvat alueet ja taantuvat paikalliskeskukset. Näille kaikille alamuodostumille on keskiarvojen perusteella tunnusomaista tilastoidun väkiluvun, työpaikkojen ja kausiväestön vähentyminen. Yhteensä taantuvissa aluemuodostumissa tilastoitu väkiluku vähentyi 63300 asukkaalla, työpaikat 84600 työpaikalla ja kausiväestön lukumäärä 44000 asukkaalla (taulukko 2). Havaittu kehitys tarkoittaa, että taantuvissa aluemuodostumissa niin alueiden pysyvä kuin osa-aikainenkin hyödyntäminen on vähentynyt. Maantieteellisesti taantuvat aluemuodostumat sijoittuvat suhteellisen tasaisesti ympäri Suomea (kuva 3).

Spatiaalisessa ryhmittelyanalyysissä muodostui kaksi uutta aluemuodostumaa. Näistä maantieteellisesti kattavampia ovat monipaikkaisuuteen nojaavat kausittain kasvavat alueet, jotka keskittyvät Itä- ja Pohjois-Suomeen (kuva 3). Kausittain kasvavat alueet jakautuivat ryhmittelyssä neljään alamuodostumaan: kausittainen kasvuydin, harvaan asutut kausittain kasvavat alueet, uudet kausittain kasvavat alueet ja erilliset kausittaiset kasvualueet. Kaikille näille aluemuodostumille on tunnusomaista väestön ja työpaikkojen lukumäärän vähentyminen kausiväestön lukumäärän kasvaessa (taulukko 2). Näitä aluemuodostumia kuvaakin niiden käytössä tapahtunut muutos: alueiden pysyvän käytön hiipuessa kausittainen käyttö on kasvanut ja määrittänyt entistä enemmän näiden alueiden kehitystä. Muutos ilmenee selkeästi tilastoista. Kausittain kasvavissa aluemuodostumissa tilastoitu väkiluku on vähentynyt yli 39 900 asukkaalla ja työpaikat yli 42500 työpaikalla, mutta kausiväestön lukumäärä on samanaikaisesti kasvanut yli 30500 asukkaalla (taulukko 2). Kausittain kasvavien alueiden aluemuodostuma on aikaisemmissa tutkimuksissa peittynyt yksipaikkaiseen tilastointiin, jonka myötä nämä alueet ovat aikaisemmin luokiteltu taantuviksi.

Aluerakenteessa nousee esille toisena uutena aluemuodostumana kehittyvät alueet, joille on keskiarvojen perusteella tyypillistä tilastoidun väkiluvun ja työpaikkojen lukumäärän vähentymi- 
nen sekä kausiväestön kasvu, mutta kokonaisuutena aluemuodostumassa väestömäärä on lisääntynyt yli 8500 asukkaalla (taulukko 2). Kehittyvien alueiden muodostumassa keskimääräinen kehitys on kuitenkin selvästi taantuvien alueiden kehitys- tä myönteisempää. Kehittyvät postinumeroalueet sijoittuvat hajautuneesti eri puolille Suomea ulottuen Uudeltamaalta Lappiin asti, mutta aluerakenteessa nämä alueet sijoittuvat usein lähelle taantuvia aluemuodostumia (kuva 3).

Taulukko 2. Väestö- ja työpaikkakehityksen yhteenlaskettu muutos aluemuodostumissa vuosina 2005-2016.

Table 2. Total change in population and employment development in spatial formations in 2005-2016.

\begin{tabular}{|c|c|c|c|c|c|c|}
\hline \multirow[t]{2}{*}{$\begin{array}{l}\text { Aluemuodostuma } \\
\text { (Spatial formation) }\end{array}$} & \multicolumn{2}{|c|}{$\begin{array}{l}\text { Väkiluku } \\
\text { (Population) }\end{array}$} & \multicolumn{2}{|c|}{$\begin{array}{l}\text { Kausiväestö } \\
\text { (Seasonal population) }\end{array}$} & \multicolumn{2}{|l|}{$\begin{array}{l}\text { Työpaikat } \\
(J o b s)\end{array}$} \\
\hline & $\mathrm{n}$ & $\%$ & $\mathrm{n}$ & $\%$ & $\mathrm{n}$ & $\%$ \\
\hline $\begin{array}{l}\text { Väestön kasvumuodostuma } \\
\text { (Population growth formation) }\end{array}$ & 14972 & 10,3 & 12046 & 11,1 & 1282 & 2,4 \\
\hline $\begin{array}{l}\text { Kasvuydin } \\
\text { (Growth core) }\end{array}$ & 156309 & 6,8 & 125617 & 6,6 & 50284 & 5,7 \\
\hline $\begin{array}{l}\text { Erillinen kasvumuodostuma } \\
\text { (Separate growth area) }\end{array}$ & 37066 & 17,7 & 91600 & 46,6 & 6312 & 3,8 \\
\hline $\begin{array}{l}\text { Erillinen työpaikkojen kasvualue } \\
\text { (Separate job growth area) }\end{array}$ & 1374 & 1,6 & 514 & 0,7 & 29568 & 59,2 \\
\hline $\begin{array}{l}\text { Erillinen väestökasvualue } \\
\text { (Separate population growth area) }\end{array}$ & 101345 & 36,2 & 57826 & 30,8 & 22441 & 22,9 \\
\hline $\begin{array}{l}\text { Kasvavat yhteensä } \\
\text { (Growing areas, total) }\end{array}$ & 311066 & 10,3 & 287602 & 11,7 & 109887 & 8,8 \\
\hline $\begin{array}{l}\text { Kausittainen kasvuydin } \\
\text { (Seasonally growing core areas) }\end{array}$ & -33273 & $-9,2$ & 21937 & 3,9 & -39499 & $-44,0$ \\
\hline $\begin{array}{l}\text { Harvaan asutut kausittain kasvavat } \\
\text { alueet } \\
\text { (Sparsely populated seasonally } \\
\text { growing areas) }\end{array}$ & -5457 & $-10,0$ & 2969 & 2,2 & -1292 & $-10,2$ \\
\hline $\begin{array}{l}\text { Uudet kausittain kasvavat alueet } \\
\text { (New seasonally growing areas) }\end{array}$ & -716 & $-2,8$ & 4735 & 9,1 & -1270 & $-12,6$ \\
\hline $\begin{array}{l}\text { Erillinen kausittainen kasvualue } \\
\text { (Separate seasonally growing area) }\end{array}$ & -474 & $-4,7$ & 919 & 4,5 & -496 & $-22,6$ \\
\hline $\begin{array}{l}\text { Kausittain kasvavat yhteensä } \\
\text { (Seasonally growing, total) }\end{array}$ & -39920 & $-8,9$ & 30560 & 3,9 & -42557 & $-37,1$ \\
\hline $\begin{array}{l}\text { Kehittyvät } \\
\text { (Developing areas) }\end{array}$ & 8536 & 1,3 & 31381 & 4,4 & -5189 & $-2,6$ \\
\hline $\begin{array}{l}\text { Erityisesti väestöllisesti taantuvat } \\
\text { alueet } \\
\text { (Stagnating areas) }\end{array}$ & -20721 & $-8,7$ & -2188 & $-0,7$ & -4785 & $-4,8$ \\
\hline $\begin{array}{l}\text { Kasvavan kunnan taantuvat alueet } \\
\text { (Stagnating areas in growing } \\
\text { municipality) }\end{array}$ & -15433 & $-5,8$ & 1373 & 0,4 & -7881 & $-9,1$ \\
\hline $\begin{array}{l}\text { Taantuvat paikalliskeskukset } \\
\text { (Stagnating local centres) }\end{array}$ & -27204 & $-3,6$ & -83804 & $-16,3$ & -31481 & $-11,8$ \\
\hline $\begin{array}{l}\text { Taantuvat yhteensä } \\
\text { (Stagnating, total) }\end{array}$ & -63358 & $-5,1$ & -84619 & $-7,3$ & -44147 & $-9,8$ \\
\hline $\begin{array}{l}\text { Yhteensä } \\
\text { (Total) }\end{array}$ & 216150 & 4,2 & 265041,4 & 5,5 & 20785 & 1,0 \\
\hline
\end{tabular}



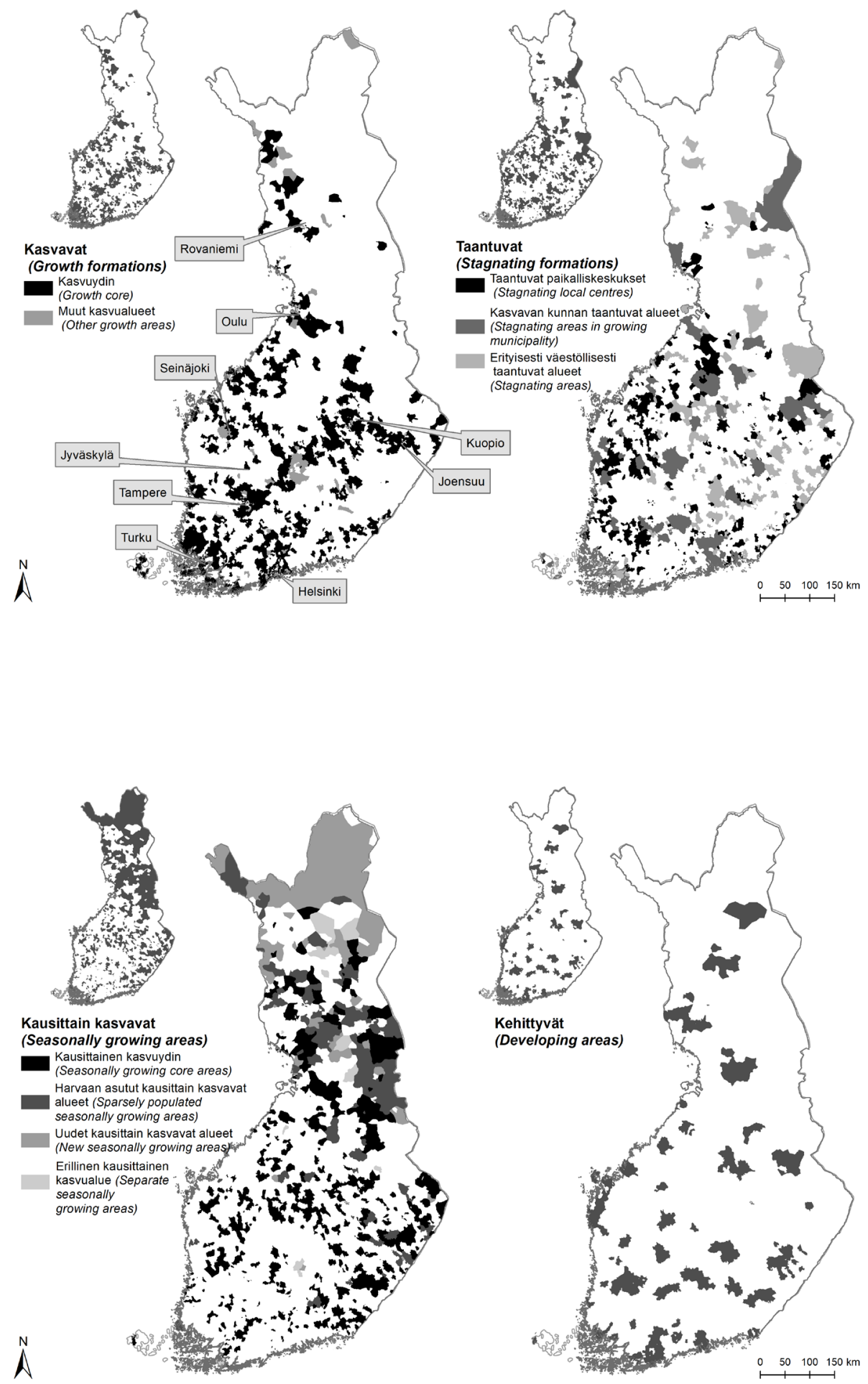

Kuva 3.

Aluerakenteen aluemuodostumat Suomessa.

Figure 3. Spatial formations of regional structure in Finland. 


\section{Aluemuodostumien esiintyvyys aluerakenteessa}

Aluemuodostumien esiintyvyyttä aluerakenteessa on kuvattu tarkemmin taulukossa 4. Väestön ja työpaikkojen lukumäärällä mitattuna suurin aluemuodostuma on kasvavat alueet, joihin sijoittuu 56 prosenttia väkiluvusta ja 62 prosenttia työpaikoista. Kasvualueet ovat myös postinumeroalueiden lukumäärässä yleisiä, sillä 33 prosenttia postinumeroalueista ryhmittyy kasvualueisiin. Kasvu näyttäytyy aluerakenteessa kuitenkin maantieteellisesti suppeana, koska maamme pinta-alasta kasvavat aluemuodostumat kattavat 21 prosenttia (taulukko 3 ).

Aluemuodostumia verrattaessa taantuvat aluemuodostumat ovat maantieteellisesti hieman yleisempiä kuin kasvumuodostumat, sillä ne kattavat pinta-alasta 26 prosenttia. Väestöä ja työpaikkoja näissä muodostumissa on kuitenkin selvästi kasvumuodostumia vähemmän, sillä näiden aluemuo- dostumien väestö- ja työpaikkaosuudet ovat 23 ja 22 prosenttia (taulukko 3). Aluerakenteessa taantuminen näyttäytyykin aikaisempaa tutkimusta suppeampana: tutkimuksessa on esimerkiksi vuosina 1995-2000 peräti 90 prosenttia Suomen pinta-alasta kuvattu taantuvaksi poismuuttoalueeksi (Hanell ym. 2002).

Väestö- ja työpaikkakriteereillä kolmanneksi suurin aluemuodostuma ovat kehittyvät alueet, joissa asuu noin 12 prosenttia väestöstä, ja joissa sijaitsee noin 10 prosenttia työpaikoista (taulukko 3 ). Tähän muodostumaan kuuluu hieman yli 14 prosenttia postinumeroalueista ja se kattaa maantieteellisesti noin 12 prosenttia Suomen pinta-alasta. Pinta-alaltaan kattavin aluemuodostuma ovat kausittain kasvavat alueet, jotka kattavat maamme pinta-alasta 41 prosenttia. Laajan pinta-alan myötä muodostumat ovat pääosin harvaan asuttuja, sillä väkiluvun ja työpaikkojen osuudet ovat näissä muodostumissa 8 ja 6 prosenttia koko maan luvuis-

Taulukko 3. Tilastoja aluemuodostumien esiintyvyydestä vuonna 2016.

Table 3. Statistics on the prevalence of spatial formations in 2016.

\begin{tabular}{|c|c|c|c|c|c|c|c|c|c|c|}
\hline \multirow[t]{2}{*}{$\begin{array}{l}\text { Aluemuodostuma } \\
\text { (Spatial formation) }\end{array}$} & \multicolumn{2}{|l|}{$\begin{array}{l}\text { Väkiluku } \\
\text { (Population) }\end{array}$} & \multicolumn{2}{|l|}{$\begin{array}{l}\text { Kausiväestö } \\
\text { (Seasonal } \\
\text { population) }\end{array}$} & \multicolumn{2}{|l|}{$\begin{array}{l}\text { Työpaikat } \\
\text { (Jobs) }\end{array}$} & \multicolumn{2}{|c|}{$\begin{array}{l}\text { Postinumeroalueet } \\
\text { (Postcode areas) }\end{array}$} & \multicolumn{2}{|l|}{$\begin{array}{l}\text { Pinta-ala } \\
\text { (Area) }\end{array}$} \\
\hline & $\mathrm{n}$ & $\%$ & $\mathrm{n}$ & $\%$ & $\mathrm{n}$ & $\%$ & $\mathrm{n}$ & $\%$ & $\mathrm{~km}^{2}$ & $\%$ \\
\hline $\begin{array}{l}\text { Väestön kasvumuodostuma } \\
\text { (Population growth formation) }\end{array}$ & 145401 & 2,7 & 108529 & 2,1 & 54471 & 2,7 & 38 & 1,3 & 2003,6 & 0,6 \\
\hline $\begin{array}{l}\text { Kasvuydin } \\
\text { (Growth core) }\end{array}$ & 2297175 & 42,9 & 1896615 & 37,0 & 875062 & 43,3 & 748 & 25,8 & 60070,0 & 18,1 \\
\hline $\begin{array}{l}\text { Erillinen kasvumuodostuma } \\
\text { (Separate growth area) }\end{array}$ & 209009 & 3,9 & 196506 & 3,8 & 167856 & 8,3 & 47 & 1,6 & 280,4 & 0,1 \\
\hline $\begin{array}{l}\text { Erillinen työpaikkojen kasvualue } \\
\text { (Separate job growth area) }\end{array}$ & 87141 & 1,6 & 78150 & 1,5 & 49921 & 2,5 & 56 & 1,9 & 3935,8 & 1,2 \\
\hline $\begin{array}{l}\text { Erillinen väestökasvualue } \\
\text { (Separate population growth area) }\end{array}$ & 279793 & 5,2 & 187810 & 3,7 & 98036 & 4,9 & 67 & 2,3 & 2178,4 & 0,7 \\
\hline $\begin{array}{l}\text { Kasvavat yhteensä } \\
\text { (Growing areas, total) }\end{array}$ & 3018519 & 56,3 & 2467610 & 48,1 & 1245346 & 61,7 & 956 & 32,9 & 68468,2 & 20,7 \\
\hline $\begin{array}{l}\text { Kausittainen kasvuydin } \\
\text { (Seasonally growing core areas) }\end{array}$ & 360581 & 6,7 & 568985 & 11,1 & 89754 & 4,4 & 525 & 18,1 & 60827,2 & 18,3 \\
\hline $\begin{array}{l}\text { Harvaan asutut kausittain kasvavat alueet } \\
\text { (Sparsely populated seasonally growing areas) }\end{array}$ & 54461 & 1,0 & 133688 & 2,6 & 12681 & 0,6 & 111 & 3,8 & 30342,8 & 9,1 \\
\hline $\begin{array}{l}\text { Uudet kausittain kasvavat alueet } \\
\text { (New seasonally growing areas) }\end{array}$ & 25224 & 0,5 & 51910 & 1,0 & 10052 & 0,5 & 56 & 1,9 & 39512,5 & 11,9 \\
\hline $\begin{array}{l}\text { Erillinen kausittainen kasvualue } \\
\text { (Separate seasonally growing area) }\end{array}$ & 10065 & 0,2 & 20560 & 0,4 & 2190 & 0,1 & 18 & 0,6 & 6554,4 & 2,0 \\
\hline $\begin{array}{l}\text { Kausittain kasvavat yhteensä } \\
\text { (Seasonally growing, total) }\end{array}$ & 450331 & 8.4 & 775143 & 15.1 & 114677 & 5.6 & 710 & 24.4 & 137236,9 & 41,3 \\
\hline $\begin{array}{l}\text { Kehittyvät } \\
\text { (Developing areas) }\end{array}$ & 642221 & 12,0 & 718574 & 14,0 & 198169 & 9,8 & 414 & 14,3 & 40759,1 & 12,3 \\
\hline $\begin{array}{l}\text { Erityisesti väestöllisesti taantuvat alueet } \\
\text { (Stagnating areas) }\end{array}$ & 237505 & 4,4 & 330966 & 6,5 & 99065 & 4,9 & 190 & 6,5 & 30195,2 & 9,1 \\
\hline $\begin{array}{l}\text { Kasvavan kunnan taantuvat alueet } \\
\text { (Stagnating areas in growing municipality) }\end{array}$ & 265294 & 4,9 & 320468 & 6,3 & 86194 & 4,3 & 235 & 8,1 & 28339,7 & 8,5 \\
\hline $\begin{array}{l}\text { Taantuvat paikalliskeskukset } \\
\text { (Stagnating local centres) }\end{array}$ & 746032 & 13,9 & 512711 & 10,0 & 267004 & 13,2 & 396 & 13,6 & 27044,9 & 8,1 \\
\hline $\begin{array}{l}\text { Taantuvat yhteensä } \\
\text { (Stagnating, total) }\end{array}$ & 1248831 & 23,2 & 1164145 & 22,8 & 452263 & 22,4 & 821 & 28,2 & 85579,8 & 25,7 \\
\hline Yhteensä (Total) & 5360008 & 100 & 5125472 & 100 & 2018879 & 100 & 2904 & 100 & 332044,0 & 100 \\
\hline
\end{tabular}


ta. Kausiväestön merkitys on tässä alueryhmässä suuri, sillä väestön kausittainen liikkuvuus lähes kaksinkertaistaa näiden kausittain kasvavien alueiden väkiluvun kesällä. Nämä alueet eivät siten ole pysyvästi autioitumassa, vaan niiden käyttö on muuttamassa luonnettaan.

\section{Pohdinta ja johtopäätökset}

Artikkelin tulokset osoittavat, että aluerakenteen kehitys on aiemmin tiedettyä moninaisempaa, kun analyysissä huomioidaan yhteen kotikuntaan perustuvien väestötilastojen lisäksi kausittain kesämökeillä asuva väestö. Osassa aluerakennetta oli tyypillistä paitsi alueen käytön muuttuminen kausittaiseksi, myös käytön lisääntyminen vuosina 2005-2016. Isossa osassa alueita väestömäärät kasvavatkin vähintään tiettyinä aikoina vuodesta, joten alueet eivät tyhjene perinteisten väestötilastojen kuvaamalla tavalla, vaan niiden käyttö muuttuu. Tämä vaikuttaa sekä vastaanottavan että lähtöalueen väestötilanteeseen. Suomessa on erilaisia asumisen ja elämisen malleja, jotka ovat aikaisemmissa tutkimuksissa peittyneet perinteisen tilastointitavan ja spatiaalisuutta huomioimattoman mallinnuksen alle.

Kausittain kasvavat alueet hallitsivat maantieteellisesti aluerakennetta, sillä Suomen pinta-alasta hieman yli 41 prosenttia kuului tähän aluemuodostumaan vuonna 2016. Näiden alueiden vetovoima linkittyy asuinympäristön liittyviin hyvinvoinnin osatekijöihin, kuten väljyyteen ja yhteyteen luontoon, jotka eroavat selvästi suurimpien kaupunkialueiden menestystä luovista niin sanotuista kovista kilpailukykytekijöistä. Aluerakenteessa kasvu oli myös tiedettyä yleisempää ja kausittain kasvavien alueiden verkosto ulottui Etelä-Suomesta Lappiin asti. Taantuminen oli aluerakenteessa aiemmin esitettyä suppeampaa ja pirstoutunutta, koska vain neljäsosa Suomen pinta-alasta luokittui kokonaan taantuvaksi alueeksi.

Tutkimuksessamme todettu aluerakenteen moninaisuus suhteessa aikaisempiin tutkimuksiin nostaa esille kolme havaintoa. Ensinnäkin voidaan todeta, että aikaisemmissa tutkimuksissa aluekehityksen tilastointi on perustunut väestön osalta yksinomaan tilastoituun väkilukuun ja yksipaikkaisuuteen, jonka myötä ihmisten muuttoliikkeen ulkopuolinen liikkuvuus ja alueiden kausittainen käyttö ovat jääneet tutkimusten ulkopuolelle. Alueiden osa-aikaista tai kausittaista käyttöä ei siten ole pystytty tunnistamaan täysimääräisesti eikä sen merkitystä aluerakenteen määrittäjänä ole ymmärretty. Alueiden kausittainen käyttö on kasvanut viime vuosina (Alasalmi ym. 2020), mikä edellyttää uusia tilastointitapoja alueiden käytön tunnistamiseksi. Tämä on tärkeää, koska monipaikkaisuuden merkitys on osalle alueita ja niiden elinvoimaisuutta huomattava (Pitkänen ym. 2017), mutta toisaalta myös siksi, että monipaikkaisuuden kestävyyttä voitaisiin arvioida.

Toiseksi artikkelin tulokset osoittavat, että alueellisuus ja alueiden välinen vuorovaikutus on pehmentänyt ja moninaistanut aluerakenteen kehitystä, vaikka alueellisuus ei tuloksissa voimakkaasti painottunutkaan. Alueet kehittyvät osana alueverkostoja, jotka alueiden välisen vuorovaikutuksen myötä määrittävät aluerakennetta (Odland 1988; Partridge ym. 2007). Alueiden kytkeytyminen toisiin alueisiin on tärkeä osa aluerakenteen kehityksen ymmärtämistä, koska hallinnolliset rajat ovat usein keinotekoisia, eivätkä ne rajoita ihmisten liikkumista alueelta toiselle. Siksi artikkelissa löydetyt aluemuodostumat kuvaavat aluerakenteen kehitystä luonnollisemmin (Assunção ym. 2006), ja tarjoavat mahdollisuuden ymmärtää alueiden aktiivisuutta ja kehitystä syvällisemmin korostaen relaatioiden merkitystä maantieteellisessä kehityksessä.

Kolmas havainto on, että kaksijakoisen kasvutaantuminen -jaottelun sijaan aluerakenteessa on useita sävyjä, joiden myötä aktiivisuutta on alueilla tasaisemmin. Aluerakenteen kehitys onkin saanut uusia ja erilaisia muotoja, joka avaa tulevaisuudessa monia kehityssuuntia. Alueellisen tasapainon näkökulmasta olisi tärkeää, että aluerakenteen kehityksen positiiviset sävyt vahvistuisivat myös kaupunkien ulkopuolella. Osaltaan tämän ratkaisee paikkariippumattoman yhteiskunnan kehitys ja erityisesti se, miten vahvasti työpaikat seuraavat tulevaisuudessa ihmisiä (Tervo 2019). Toisaalta kyse on myös aidosti siitä, että tunnustetaan vaihtoehtoja keskuksien leviämisvaikutuksiin perustuvalle aluekehittämiselle (Lehtonen 2015a). Aluekeskus- ja innovaatiopolitiikkaan pohjautuva aluepolitiikka ei tunnista esimerkiksi kausittain kasvavien alueiden vahvuuksia. Iso kysymys liittyy myös kausiväestön verotukseen, jota tukemaan tarvitaan lisää tutkimusta monipaikkaisuuden tilastointikäytännöistä mutta myös oikeudellisista vaikutuksista mukaan lukien verotusoikeus (Valtionvarainministeriö 2018).

Tarve uudelle tiedolle aluerakenteen kehityksestä on suuri, koska esimerkiksi aluesuunnittelussa tulisi voida huomioida kausittain kehittyvien alueiden kysyntää infrastruktuurille ja palveluille. Kausiväestö muuttaa palvelujen maantieteellistä kysyntää vuoden aikana ja tarjoaa esimerkiksi maaseudulle uusia mahdollisuuksia vahvistaa kausittaisia palveluja (Lehtonen ym. 2019), jos kausiväestö tunnistetaan osaksi alueita käyttävää väestöä. Aluerakenteen moninaisuuden tunnistaminen on 
olennaista myös aluekehityksen todellisen tilannekuvan tuottamisessa aluekehittämisen ja -politiikan tarpeisiin. Puutteellinen tieto alueiden käytöstä ja käyttötarpeista voi johtaa infrastruktuurin alikehittymiseen tai harhaiseen kuvaan sen vajaakäytöstä, ja heikentää näin alueiden kehitysedellytyksiä tulevaisuudessa (Weber 2012). Edellä kuvattu uhkakuva koskettaa erityisesti kausittain kasvaneita alueita ja niiden tulevaa kehitystä. Kun ihmiset liikkuvat entistä enemmän, heikkenee pysyvään asumiseen pohjautuvan tilastoinnin kyky tunnistaa alueiden käyttöä ja aluerakennetta. Siksi monipaikkaiselle asumiselle tulisi tulevaisuudessa kehittää seurattava tilastointikäytäntö, jonka tulisi ulottua myös aluerakenteen havainnointiin aluekehityksen eri sävyjen havainnoimiseksi.

\section{KIRJALLISUUS}

Adamiak, C., Pitkänen, K. \& Lehtonen, O. (2017) Seasonal residence and counterurbanization: the role of second homes in population redistribution in Finland. GeoJournal 82(5) 1035-1050. https://doi.org/10.1007/s10708-016-9727-x

Adamiak, C., Vepsäläinen, M., Strandell, A., Hiltunen, M., Pitkänen, K., Hall, M., Rinne, J., Hannonen, O., Paloniemi, R. \& Åkerlund, U. (2015) Second home tourism in Finland: Perceptions of citizens and municipalities on state and development of second home tourism. Reports of Finnish Environment Institute 22/2015. <http://hdl.handle.net/10138/155090>

Alasalmi, J., Busk, H., Holappa, V., Huovari, J., Härmälä, V., Kotavaara, O., Lehtonen, O., Muilu, T., Vihinen, H. \& Rusanen, J. (2020) Työn ja työvoiman alueellinen liikkuvuus ja monipaikkainen väestö. Valtioneuvoston selvitys- ja tutkimustoiminnan julkaisuja 12/2020. <http://urn.fi/URN:ISBN:978-952-287-928-8>

Assunção, R., Neves, M.C., Camara, G. \& Freitas, C. (2006) Efficient regionalization techniques for socio-economic geographical units using minimum spanning trees. International Journal of Geographical Information Science 20(7) 797-811. https://doi.org/10.1080/13658810600665111

Alueellinen kehittyneisyys: tutkimus elinolojen ja hyvinvoinnin alueellisista eroista 1975 (1979) Valtioneuvoston kanslian julkaisuja 3. Helsinki.

Aro, T. (2007) Valikoiva muuttoliike osana pitkän aikavälin maassamuuttokehitystä. Yhteiskuntapolitiikka 72(4) 371-379.

Aro, T. (2015) Kaupunkien elinvoiman vertailuanalyysi 2005-2013. 1.4.2019. <http://www.timoaro.fi/kaupunkien-elinvoiman-vertailuanalyysi-2005-2013/>

Aronen, K. \& Siirilä, S. (1986) Hyvinvointierot ja alueellinen erilaistuneisuus. Tampereen yliopisto, Tampere.

Combes, P.-P., Mayer, T. \& Thisse, J.-F. (2008) Economic Geography.The Integration of Regions and
Nations. Princeton University Press, Princeton. https://doi.org/10.2307/j.ctvcm4h9k

Cumbers, A. \& MacKinnon, D. (2004) Introduction: Cluster in Urban and Regional Development. Urban Studies 41(5/6) 959-969. https://doi.org/10.1080/00420980410001675896

Desjeux, Y., Dupraz, P., Kuhlman, T., Paracchini, M.-L., Michels, R., Maignéd, E. \& Reinhard, S. (2015) Evaluating the impact of rural development measures on nature value indicators at different spatial levels: Application to France and The Netherlands. Ecological Indicators 59(12) 41-61. https://doi.org/10.1016/j.ecolind.2014.12.014

Felipe, J., Utsav, K., Arnelyn, A. \& Bacate, M. (2012) Product complexity and economic development. Structural Change and Economic Dynamics 23(1) 36-68. https://doi.org/10.1016/j.strueco.2011.08.003

Fujita, M., Krugman, P. \& Venables, A. (1999) The spatial economy - cities, regions and international trade. The MIT Press, Cambridge. https://doi.org/10.7551/mitpress/6389.001.0001

Glaeser, E. (1998). Are cities dying? Journal of Economic Perspectives 12(2) 139-160. https://doi.org/10.1257/jep.12.2.139

Hanell, T., Aalbu, H. \& Neubauer, J. (2002) Regional development in the Nordic countries 2002. Nordregio Report 2:2002.

Hartigan, J. (1975) Clustering Algorithms. Wiley, New York.

Haukkala, T. (2011) Monipaikkaisuus - ilmiö ja tulevaisuus. Sitran selvityksiä 54. <https://media.sitra. fi/2017/02/27172901/SelvityksiC3A454-2.pdfs

Helminen, V., Rita, H., Ristimäki, M. \& Kontio, P. (2012) Commuting to the centre in different urban structures. Environment and Planning $B$ : Planning and Design 39:2 247-261. https://doi.org/10.1068/b36004

Helminen, V., Nurmio, K., Rehunen, A., Ristimäki, M., Oinonen, K., Tiitu, M., Kotavaara, O., Antikainen, H. \& Rusanen, J. (2014) Kaupunki-maaseutu-alueluokitus: Paikkatietoihin perustuvan alueluokituksen muodostamisperiaatteet. Suomen ympäristökeskuksen raportteja 25/2014. <http://hdl.handle.net/ 10138/135861>

Jauhiainen, S. \& Huovari, J. (2013) Kuntarakenne ja alueiden elinvoima - laskelmia väestöstä, työpaikoista ja kuntataloudesta. Kunnallisalan kehittämissäätiön Tutkimusjulkaisu-sarjan julkaisu nro 72 . $\leq$ https://kaks.fi/wp-content/uploads/2013/03/Jauhiainen Huovari.pdfs

Kainulainen, S., Rintala, T. \& Heikkilä, M. (2001) Hyvinvoinnin alueellinen erilaistuminen 1990-luvun Suomessa. Stakes tutkimuksia 114.

Kaltenborn, B. P. (1998) The alternate homes - motives of recreation home use. Norsk Geografisk Tidsskrift 
- Norwegian Journal of Geography 52(3) 121-134. https://doi.org/10.1080/00291959808552393

Keränen, R., Malinen, P., Keränen, H. \& Heiskanen, T. (1993) Suomen maaseututyyppien alueellistaminen. Ylä-Savon Instituutti, Tutkimusraportti 6:1.

Kotavaara, O., Antikainen, H. \& Rusanen, J. (2011) Population change and accessibility by road and rail networks: GIS and statistical approach to Finland 19702007. Journal of Transport Geography 19(4) 926-935. https://doi.org/10.1016/j.jtrangeo.2010.10.013

Kotavaara, O., Antikainen, H., Marmion, M. \& Rusanen, J. (2012) Scale in the effect of accessibility on population change: GIS and a statistical approach to road, air and rail accessibility in Finland, 1990-2008. The Geographical Journal 178(4) 366-382. https://doi.org/10.1111/j.1475-4959.2012.00460.x

Krugman, P. (1991) Increasing Returns and Economic Geography. The Journal of Political Economy 99(3) 473-499. https://doi.org/10.1086/261763

Lehtonen, O. (2015a) Space-time dependence in regional development: the geospatial approach to understanding the development processes in small-scale areas of Finland. University of Eastern Finland, Dissertations in social sciences and business studies No 118. <https://epublications.uef.fi/pub/urn isbn 978-952-61-1765-2/index en.html>

Lehtonen, O. (2015b) Työpaikkojen kasvualueiden potentiaaliset leviämis- ja supistumisvaikutukset Suomessa. Terra 127(2) 67-81.

Lehtonen, O. \& Tykkyläinen, M. (2009) Muuttoliikkeen alueelliset muodostumat ja pulssi Suomessa 19802006. Terra 121(2) 119-137.

Lehtonen, O. \& Tykkyläinen, M. (2010) Self-reinforcing spatial clusters of migration and socioeconomic conditions in Finland in 1998-2006. Journal of Rural Studies 26(4) 361-373. https://doi.org/10.1016/j.jrurstud.2010.02.003

Lehtonen, O. \& Tykkyläinen, M. (2012a) Syrjäisten alueiden kilpailukyky keskushakuisessa kehityksessä esimerkkinä Itä-Suomi. Maaseudun Uusi Aika 20:2 5-21.

Lehtonen, O. \& Tykkyläinen, M. (2012b) Path dependence in net migration during the ICT boom and two other growth periods: the case of Finland 1980-2013. Journal of Evolutionary Economics 28: 547-564. https://doi.org/10.1007/s00191-017-0518-4

Makkonen, T. \& Inkinen, T. (2015) Geographical and temporal variation of regional development and innovation in Finland. Fennia 193(1) 134-147.

Malinen, P. \& Kytölä, L. \& Keränen, H. \& Keränen, R. (2006) Suomen maaseututyypit 2006. Maa- ja metsätalousministeriö, Helsinki.

Martin, R. \& Sunley, P. (2006) Path dependence and regional economic evolution. Journal of Economic Geography 6(4) 395-437. https://doi.org/10.1093/jeg/lb1012

MDI (2019) Väestöennuste 2040. 12.3.2020. <https:// www.mdi.filennuste2040rs
Müller, D. K. \& Hall, M. (2003) Second homes and regional population distribution: On administrative practices and failures in Sweden. Espace, Populations, Sociétés 2 251-261. https://doi.org/10.3406/espos.2003.2079

Mökkibarometri (2016) FCG Finnish Consulting Group Oy. Maa- ja metsätalousministeriö, Saaristoasiain neuvottelukunta, Helsinki. <https://mmm.fi documents/1410837/1880296/Mokkibarometri+ 2016/7b69ab48-5859-4b55-8dc2-5514cdfa6000>

Niemi, E. (2002) Menestyksen mittarit. Tietoaika 1/2002 4-12.

Odland, J. (1988) Spatial autocorrelation. Sage Publications, Newbury Park.

Openshaw, S. \& Alvanides, S. (1999) Zone design for planning and policy analysis. Teoksessa Stillwell, J., Geertman, S. \& Openshaw, S. (toim.) Geographical Information and Planning, 299-315. Springer, Berlin. https://doi.org/10.1007/978-3-662-03954-0_16

Openshaw, S. \& Wymer, C. (1995) Classifying and regionalizing census data. Teoksessa Openshaw, S. (toim.) Census Users' Handbook, 239-269. Geoinformation International, Cambridge.

Partridge, M., Bollman, R., Olfert, M. R. \& Alasia, A. (2007) Riding the wave of urban growth in the countryside: spread, backwash, or stagnation? Land Economics 83(2) 128-152. https://doi.org/10.3368/le.83.2.128

Pettie, S. \& Ramachandran, V. (2002) An Optimal Minimum Spanning Tree Algorithm. Journal of the ACM 49(1) 16-34. https://doi.org/10.1145/505241.505243

Pitkänen, K. \& Vepsäläinen, M. (2008) Foreseeing the future of second home tourism. The case of Finnish media and policy discourse. Scandinavian Journal of Hospitality and Tourism 8(1) 1-24. https://doi.org/10.1080/15022250701880729

Pitkänen, K. \& Strandell, A. (2018) Suomalaisen maaseudun monipaikkaisen asumisen muodot ja tulevaisuuden kehitys. Maaseutuja tulevaisuudessa. Maaseutupolitiikan 30-vuotisjuhlanumero. Maaseudun Uusi Aika 26(2-3) 6-23. <http://www.mua-lehti.fil wp-content/uploads/2018/10/pitkanen-ja-strandell.pdss

Polèse, M \& Shearmur, R. (2004) Is distance really dead? Comparing location patterns over time in Canada. International Regional Science Review 27(4) 431-457. https://doi.org/10.1177/0160017604267637

Rissanen, R., Rehunen, A., Kalenoja, H., Ahonen, O., Mäkelä, T., Rantala, J. \& Pöllänen, M. (2013) ALLI-kartasto - Suomen aluerakenteen ja liikennejärjestelmän kehityskuvan pohjustus. Rakennetun ympäristön osasto, Helsinki.

Ristimäki, M., Tiitu, M., Helminen, V., Nieminen, H., Rosengren, K., Vihanninjoki, V., Rehunen, A., Strandell, A., Kotilainen, A., Kosonen, L., Kalenoja, H., Nieminen, J., Niskanen, S. \& Söderström, P. (2017) Yhdyskuntarakenteen tulevaisuus kaupunkiseuduilla - kaupunkikudokset ja vyöhykkeet. Suomen 
ympäristökeskuksen raportteja 4/2017. < $\underline{\text { htp: }: / / h d l}$. handle.net/10138/176782>

Rosenthal, S. \& Strange, W. (2004) Evidence on the Nature and Sources of Agglomeration Economics. Teoksessa Henderson, J. \& Thiesse, J. (toim.) Handbook of Regional and Urban Economics, 2120-2171. Elsevier, Amsterdam. https://doi.org/10.1016/S1574-0080(04)80006-3

Rusanen, J., Muilu, T., Colpaert, A. \& Naukkarinen, A. (2003) Georeferenced data as a tool for monitoring the concentration of population in Finland in 1970-1998. Fennia 181(2) 129-144.

Saaristoasiain neuvottelukunta (2006) Mökkiläiset kuntapalvelujen käyttäjinä. Sisäasianministeriön julkaisu 24/2006. <https://mmm.fi/documents/ 1410837/1948019/Mokkilaiset kuntapalvelujen kayttajina 2006.pdf/287dd4d3-7b2c-4344-9fbacbd758721fad/Mokkilaiset kuntapalvelujen_kayttajina 2006.pdf.pdfs

Shearmur, R. \& Polése, M. (2007) Do local factors explain local employment growth? Evidence from Canada 1971-2001. Regional Studies 41(4) 453-471. https://doi.org/10.1080/00343400600928269

Suomen ympäristökeskus (2013) Yhdyskuntarakenteen seurannan aineistot. Helsinki.

Tervo, H. (2000) Suomen aluerakenne ja siihen vaikuttavat tekijät. Kansantaloudellinen aikakauskirja 96:3 398-415.

Tervo, H. (2010) Cities, hinterlands and agglomeration shadows: Spatial developments in Finland during 1880-2004. Explorations in Economic History 47(4) 476-486. https://doi.org/10.1016/j.eeh.2010.05.002

Tervo, H. (2019) Kaupungistuminen kiihtyy - säilyykö alueellinen tasapaino? Kansantaloudellinen aikakauskirja 115:2 254-262. <https://www.talous tieteellinenyhdistys.fi/wp-content/uploads/2019/06/ LOW3 31086773 KAK sisus $22019 \quad 176 \times 245$ Copy-42-50.pdf

Tervo, H., Helminen, V., Rehunen, A. \& Tohmo, T. (2018) Onko urbanisaatio maaseudun turma? Kaupunkien väestönkasvun vaikutukset erityyppisen maaseudun väestökehitykseen Suomessa ajanjaksolla 1990-2015. Yhteiskuntapolitiikka 83:3 258-271. <http://urn.fi/URN:NBN:fi-fe2018061325774>
Tilastokeskus (2016) Paavo - Postinumeroalueittainen avoin tieto. Helsinki.

Tilastokeskus (2006) SuomiCD. Helsinki.

Tilastokeskus (2020) Vapaa-ajan osallistuminen. 11.3.2020. <http://www.stat.filtil/vpa/tau.html>

Työ- ja elinkeinoministeriö (2020) Kasvusopimukset. 11.3.2020. <https://tem.fi/kasvusopimukset>

Toivonen, T., Jaakkola, T. \& Vuori, M. (2010) Solmukohta vai pussinperä? Helsingin yliopiston maantieteen laitoksen julkaisuja B 55. <http://hdl.handle. net/10138/16177>

Vaattovaara, M. (1998) Pääkaupunkiseudun sosiaalinen erilaistuminen. Karisto Oy, Hämeenlinna.

Valtionvarainministeriö (2018) Millaista monipaikkaisuutta Suomeen - Selvitys kaksoiskuntalaisuudesta. Valtiovarainministeriön julkaisu 3/2018. <http://urn. fi/URN:ISBN:978-952-251-927-6>

Vartiainen, P. (1995) Kaupunkiverkko: Kuvausjärjestelmän kehittäminen kansallisiin ja kansainvälisiin tarpeisiin. Ympäristöministeriö, Alueidenkäytön osaston Tutkimusraportti 3/1995.

Weber G. (2012) Aktuelle Herausforderungen ländlicher Räume und ihre Raumbilder prägende Wirkung. Teoksessa Dornik, W. \& Grasmug, R. (toim.) Möglichkeiten / Abhängigkeiten. Strukturwandel in der Südoststeiermark. Schriften aus dem "Museum im Tabor" Feldbach 10, 173-184. Leykam, Feldbach-Graz.

Weichhart, P. (2015) Residential multi-locality: in search of theoretical frameworks. Tijdschrift voor Economische en Sociale Geografie 106(4) 378-391. https://doi.org/10.1111/tesg.12156

Yurui, L., Hualou, L. \& Yansui, L. (2015) Spatio-temporal pattern of China's rural development: A rurality index perspective. Journal of Rural Studies 38(4) 12-26. https://doi.org/10.1016/j.jrurstud.2015.01.004 
Liite 1.

Keskimääräinen kehitys ryhmittelyssä käytetyissä muuttujissa aluemuodostumittain vuosina 2005-2016.

Appendix 1 .

Average development in the variables used in the spatial clustering by spatial formations in 2005-2016.

\begin{tabular}{|c|c|c|c|c|c|c|}
\hline \multirow[t]{2}{*}{$\begin{array}{l}\text { Alueryhmä } \\
\text { (Spatial formation) }\end{array}$} & \multicolumn{3}{|c|}{\begin{tabular}{|l|} 
Väestö- ja työpaikkakehitys 2005-2016 \\
(Population and job development 2005-2016)
\end{tabular}} & \multicolumn{3}{|c|}{$\begin{array}{l}\text { Työssäkäyntimuuttujat } 2016 \\
\text { (Commuting variables 2016) }\end{array}$} \\
\hline & \begin{tabular}{|l|} 
kausiväki (\%) \\
(Change of \\
seasonal \\
population (\%))
\end{tabular} & $\begin{array}{l}\text { työpaikat }(\%) \\
\text { (Change of } \\
\text { jobs (\%)) }\end{array}$ & \begin{tabular}{|l|} 
väkiluku (\%) \\
(Change of \\
population (\%))
\end{tabular} & $\begin{array}{l}\text { Työmatka yli } \\
100 \mathrm{~km}(\%) \\
\text { (Commuting } \\
\text { distance over } \\
100 \mathrm{~km}(\%) \text { ) } \\
\end{array}$ & $\begin{array}{l}\text { Keskityömatka } \\
(\mathrm{km}) \\
\text { (Commuting } \\
\text { distance }(\mathrm{km}))\end{array}$ & $\begin{array}{l}\text { Työpaikka- } \\
\text { omavaraisuus } \\
\text { (Workplace } \\
\text { self-sufficiency) }\end{array}$ \\
\hline $\begin{array}{l}\text { Väestön kasvumuodostuma } \\
\text { (Population growth formation) }\end{array}$ & 13,0 & 16,0 & 11,8 & 5,8 & 23,2 & 83,0 \\
\hline $\begin{array}{l}\text { Kasvuydin } \\
\text { (Growth core) }\end{array}$ & 7,7 & 6,4 & 3,7 & 3,1 & 21,3 & 75,4 \\
\hline $\begin{array}{l}\text { Erillinen kasvumuodostuma } \\
\text { (Separate growth area) }\end{array}$ & 10,8 & 8,4 & 20,2 & 4,2 & 19,2 & 231,4 \\
\hline $\begin{array}{l}\text { Erillinen työpaikkojen kasvualue } \\
\text { (Separate job growth area) }\end{array}$ & 3,2 & 209,8 & 5,6 & 4,8 & 26,0 & 117,2 \\
\hline $\begin{array}{l}\text { Erillinen väestökasvualue } \\
\text { (Separate population growth } \\
\text { area) }\end{array}$ & 43,7 & 41,5 & 71,4 & 3,6 & 20,4 & 92,4 \\
\hline $\begin{array}{l}\text { Kausittainen kasvuydin } \\
\text { (Seasonally growing core areas) }\end{array}$ & 1,9 & $-41,4$ & $-15,2$ & 3,3 & 25,4 & 52,3 \\
\hline $\begin{array}{l}\text { Harvaan asutut kausittain } \\
\text { kasvavat alueet } \\
\text { (Sparsely populated seasonally } \\
\text { growing areas) }\end{array}$ & 2,6 & $-32,8$ & $-19,0$ & 11,9 & 54,0 & 54,5 \\
\hline $\begin{array}{l}\text { Uudet kausittain kasvavat alueet } \\
\text { (New seasonally growing areas) }\end{array}$ & 8,9 & $-7,6$ & $-12,3$ & 23,7 & 104,8 & 56,0 \\
\hline $\begin{array}{l}\text { Erillinen kausittainen kasvualue } \\
\text { (Separate seasonally growing } \\
\text { area) }\end{array}$ & 5,2 & $-14,4$ & $-8,9$ & 16,1 & 50,8 & 53,5 \\
\hline $\begin{array}{l}\text { Kehittyvät alueet } \\
\text { (Developing areas) }\end{array}$ & 3,7 & $-5,4$ & $-4,3$ & 3,1 & 23,5 & 62,0 \\
\hline $\begin{array}{l}\text { Erityisesti väestöllisesti taantuvat } \\
\text { alueet } \\
\text { (Stagnating areas) }\end{array}$ & $-1,4$ & $-13,0$ & $-11,0$ & 7,0 & 30,4 & 83,9 \\
\hline $\begin{array}{l}\text { Kasvavan kunnan taantuvat alueet } \\
\text { (Stagnating areas in growing } \\
\text { municipality) }\end{array}$ & $-1,3$ & $-14,9$ & $-10,6$ & 4,0 & 25,5 & 70,4 \\
\hline $\begin{array}{l}\text { Taantuvat paikalliskeskukset } \\
\text { (Stagnating local centres) }\end{array}$ & $-12,6$ & $-17,3$ & $-9,1$ & 3,1 & 19,8 & 140,2 \\
\hline
\end{tabular}

